\title{
Detection of Rice Transitory Yellowing Virus (RTYV) in Infected Rice Plants and Insect Vectors by Simplified ELISA
}

\author{
Yoshiyuki TAKaHASHI*, Toshihiro OMURA**, Takaharu HAYASHI***, \\ Kenichiro SHOHARA* and Tsuneo TsuchIZAKI**
}

Key words: rice transitory yellowing virus, insect vector, simplified ELISA.

Rice transitory yellowing virus (RTYV) transmitted by Nephotettix leafhoppers in a persistent manner causes yellowing of the lower leaves and reduced tillering in infected rice plants ${ }^{1)}$. Symptoms of the disease closely resemble those of tungro, orange leaf disease and physiological disorders ${ }^{2)}$. This disease has been reported to occur in Taiwan ${ }^{1)}$, Okinawa ${ }^{3)}$, China and Thailand4). Methods to detect the virus include a transmission test using leafhoppers, electron microscopic (EM) examination, and western blot analysis using peroxidase conjugated concanavalin $A(\text { Con } \mathbf{A})^{5}$. However, each method has its shortcoming; the transmission test takes over one month to obtain results, EM is not suitable for massinspection, and Con A can not detect the virus antigen in insect vectors. Recently, serological detection of virus antigens has become possible owing to successful virus purification which enables specific antiserum production ${ }^{4}$. This paper describes the establishment of a massinspection method for the detection of RTYV in rice plants and viruliferous insects by comparing results from the passive hemagglutination test (PHA), latex flocculation method (LF), enzyme-linked immunosorbent assay (ELISA) and simplified ELISA ${ }^{6}$.

RTYV-infected rice plants were maintained and proliferated using viruliferous Nephotettix nigropictus which had been fed on infected rice plants (cv. Koshihikari). The antiserum against the purified virus (T. Hayashi, unpublished) had a titer of $1: 500$ in the precipitin ring interface test.

We first examined PHA. Formalinized sheep erythrocytes) were sensitized with antiserum $^{8,9)}$. The virus antigens in viruliferous insects were successfully detected (data not shown). However, we could not detect them in infected plants due to the inhibition of hemagglutination in PHA.

For latex sensitization with antiserum, we used the procedure of Bercks and Querfurth ${ }^{10)}$.

* Institute of Japan Plant Protection Association, Kessoku, Ushiku, Ibaraki 300-12, Japan 日本植物 防寝協会研究所

** National Agriculture Research Center, Tsukuba, Ibaraki 305, Japan 農林水産省農業研究センター

*** National Institute of Agrobiological Resources, Tsukuba, Ibaraki 305, Japan 農林本産省生物 資源研究所

1) Shikata, E. (1972). CMI/ABB Descriptions of Plant Viruses. No. 100. 2) Su, H.J. (1969). In Proc. Symp. at the IRRI, John Hopkins Press, Baltimore. pp. 13-21. 3) Saito, Y., Inoue, H. and Satomi, H. (1978). Ann. Phytopath. Soc. Japan 44: 666-669. 4) Inoue, H., Omura, T., Hayashi, T., Morinaka, T., Putta, M., Chettanachit, D., Parejarearn, A.. Disthaporn, S. and Kadkao, S. (1986). Technical Bulletin of Tropical Agriculture Research Center. No. 21. pp. 65-77. 5) Hayashi, T. and Minobe, Y. (1986). Ann. Phytopath. Soc. Japan 52: 152 (Abstr.). 6) Takahashi, Y., Omura, T., Shohara. K. and Tsuchizaki, T. (1987). Ibid. 53: 254-257. 7) Cox, C.D. (1956). J. Lab. Clin. Med. 48: 298303. 8) Boyden, S.V. (1951). J. Exp. Med. 93: 107-120. 9) Stavitsky, A.B. (1954). J. Immunol. 72: 360-367. 
LF could not detect virus antigens in infected leaves due to non-specific flocculation, but it could detect the virus antigens in viruliferous insects when $0.01 \mathrm{M}$ citrate buffer containing $0.85 \%$ $\mathrm{NaCl}, \mathrm{pH} 6.0$ (CBS), was used as an extraction buffer.

Thus, these two methods could not detect the virus antigens in infected plants, but could those in viruliferous insects. Tests using the ELISA described below showed that these insects exhibited $A_{410}$ value $>1.5$, i.e., the sensitivity was low in both methods. We therefore do not recommend these methods for the detection of RTYV.

Standard ELISA ${ }^{11)}$ was tested using microplates coated with $5 \mu \mathrm{g} / \mathrm{ml}$ of $\gamma$-globulin, and the conjugate of alkaline phosphatase with $\gamma$-globulin diluted to $1: 400$. The absorbance at 410 $\mathrm{nm}$ was measured by MR580 microplate autoreader (Dynatech Laboratories, Inc.) $1 \mathrm{hr}$ after the addition of substrate.

The effect of the homogenizing buffers on the detection of the virus antigens was studied. Infected rice leaves or viruliferous insects were macerated in $0.01 \mathrm{M}$ phosphate buffer, $\mathrm{pH} 7.0$ (PB), $0.01 \mathrm{M} \mathrm{PB}$ containing $0.85 \% \mathrm{NaCl}$ and $0.05 \%$ Tween 20, pH 7.4 (PBS-T), CBS, pH 6.0

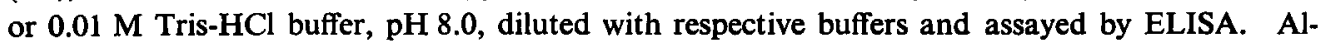
though there was little difference in the sensitivity among buffers for the detection of virus antigens, PBS-T showed the lowest non-specific reaction to healthy homogenates for both plants and insects. Based on these results, PBS-T was used as the extraction and dilution buffer.

Using the ELISA method described above, the virus was detected in the roots, tillering nods, stalks and leaves of infected rice plants at dilutions of up to 6,400,25,600, 25,600 and 25,600 times, respectively. This method was also used to detect viruliferous insects. Individual leafhoppers were homogenized with $0.4 \mathrm{ml}$ PBS-T. While individual insects exposed to virus for 20 days gave $A_{410}$ values ranging continuously from 0 to $>1.5$, all unexposed leafhoppers gave $A_{410}$ values $<0.08$ (data not shown, refer Table 1). The insects which gave an $A_{\mathbf{4 1 0}}$ value $\geqq 0.1$ were counted as viruliferous insects. No significant difference in $A_{\mathbf{4 1 0}}$ values was observed between insects of different sex. The maximum dilution giving a positive reaction for individual viruliferous insect was 4,260 times.

Simplified ELISA in which the number of manipulations is reduced by simultaneous incubation of virus antigen and conjugate with solid-phase antibody was tested ${ }^{12)}$. The $\gamma$-globulin concentration and conjugate used were the same as those for standard ELISA. The effect of the incubation time on the sensitivity of simplified ELISA was studied. A $50 \mu \mathrm{l}$ conjugate diluted to $1: 100$ was mixed with a $150 \mu$ sample in each well making the final conjugate dilution $1: 400$. When the sample-conjugate mixtures were incubated for $0.5,1$ and $2 \mathrm{hr}$ at $37 \mathrm{C}$, the dilution end points of the infected leaves were $12,800,12,800$ and 25,600 times, respectively. These results demonstrate that the sensitivity of the simplified ELISA is the same as that of the standard ELISA. The simplified version was also used to detect RTYV in viruliferous insects. The methods were the same as those reported before ${ }^{6}$ except that the incubation period was $30 \mathrm{~min}$. While the $A_{410}$ values for insects not exposed to the virus were less than 0.05 , those for virusexposed insects ranged continuously (Table 1 ).

To confirm the reliability of the simplified ELISA for detecting virus antigens in insect vectors, the infectivity of viruliferous insects was examined and each insect was then tested by simplified ELISA. For the transmission test and detection of virus antigens in insect vectors, viruliferous insects were individually transferred onto test seedlings for 2 days, then used for serological examination as described above. The insects that transmitted virus in the assays were counted as active transmitters. Rice cultivar Taichung Native 1 (TN1) and Koshihikari were used as test plants. As shown in Table 2, all insects that transmitted the virus gave positive reactions and all insects that gave negative reactions were non-transmitters These results prove the reliability of the simplified ELISA for the detection of viruliferous insects of RTYV.

10) Bercks, R. and Querfurth, G. (1971). J. gen. Virol. 12: 25-32. 11) Clark, M.F. and Adams, A.N. (1977). Ibid. 34: 475-483. 12) Stobbs, L.W. and Barker, D. (1985). Phytopathology 75: 492-495. 
Table 1. Detection of RTYV in individual leafhoppers by simplified ELISA

\begin{tabular}{|c|c|c|c|c|}
\hline \multirow{3}{*}{$\begin{array}{l}\text { A410 values } \\
\text { in ELISA }\end{array}$} & \multicolumn{4}{|c|}{ Number of leafhoppersa) } \\
\hline & \multicolumn{2}{|c|}{ Unexposed } & \multicolumn{2}{|c|}{ Exposed } \\
\hline & male & female & male & female \\
\hline $0.00-0.05$ & 37 & 29 & 110 & 110 \\
\hline $0.05-0.1$ & 0 & 0 & 13 & 13 \\
\hline $0.1-0.2$ & 0 & o & 4 & 13 \\
\hline $0.2-0.4$ & 0 & 0 & 4 & 4 \\
\hline $0.4-0.6$ & 0 & 0 & 13 & 11 \\
\hline $0.6-0.8$ & 0 & 0 & 16 & 6 \\
\hline $0.8-1.0$ & 0 & 0 & 6 & 10 \\
\hline $1.0-1.5$ & 0 & $\mathbf{0}$ & 24 & 13 \\
\hline $1.5-$ & 0 & 0 & 2 & 8 \\
\hline
\end{tabular}

a) Nephotettix nigropictus.

Table 2. The transmissibility of RTYV by leafhoppers which showed positive or negative reaction in the simplified ELISA

\begin{tabular}{|c|c|c|c|c|c|c|}
\hline \multirow{3}{*}{ Cv. of rice } & \multirow{3}{*}{$\begin{array}{l}\text { Exp. } \\
\text { no. }\end{array}$} & \multicolumn{5}{|c|}{ No. of insects } \\
\hline & & \multicolumn{3}{|c|}{ Simplified ELISA ${ }^{a)}$} & \multicolumn{2}{|c|}{ Transmission test } \\
\hline & & Total & Positive & Negative & Transmitters & Non-transmitters \\
\hline \multirow{2}{*}{ TN1 } & 1 & 50 & 27 & 23 & $\begin{array}{r}10 \\
0\end{array}$ & $\begin{array}{l}17 \\
23\end{array}$ \\
\hline & $2^{\mathrm{b})}$ & 50 & 20 & 30 & $\begin{array}{l}5 \\
0\end{array}$ & $\begin{array}{l}15 \\
30\end{array}$ \\
\hline \multirow{2}{*}{ Koshihikari } & 1 & 50 & 17 & 33 & $\begin{array}{r}10 \\
0\end{array}$ & $\begin{array}{r}7 \\
33\end{array}$ \\
\hline & 2 & 50 & 19 & 31 & $\begin{array}{r}13 \\
0\end{array}$ & $\begin{array}{r}6 \\
31\end{array}$ \\
\hline
\end{tabular}

a) The leafhoppers which gave $A_{410}$ value of $\geqq 0.1$ in the simplified ELISA were counted as positive.

b) The acquisition feeding period was 5 days.

Based on our results, we recommend the simplified ELISA for the detection of RTYV because the process is much simpler than the standard ELISA. Also, plates coated with $\gamma$-globulin could be successfully stored at $4 \mathrm{C}$, and the results could be obtained within $2 \mathrm{hr}$. Simplified ELISA should be very useful for epidemiological studies in field inspection of RTYV.

\section{和 文 摘 要}

高橋義行・大村敏博・林 隆治・厈原監一郎・土崎常男：簡易ELISA法によるイネ黄葉ウイルス(RTYV) の䍜病イネおよび保毒虫からの検出

血清学的手法を用いて RTYV の検出を試みた。赤血球凝集反応法およびラテックス㠜集反応法の場合， ウイルスは罹病イネからはそれぞれ反応抑制や非特異反応のために検出できなかったが，保毒クロスジッマ グロヨコパイからは蝀内のウイルス濃度が高い場合にのみ検出できた。ELISA 法では罹病イネ葉の 25,600 倍希积まで，保毒蚆らは 4,260 倍希釈まで検出できた。簡易 ELISA 法は，短時間の処理でELISA 法と同等の感度を示した。云搬試験の結果と比較したところ，本ウイルスを层搬した虫は必す簡易 ELISA 法で倹出され，さらに伝搬試験では検出できなかった保毒虫からすウイルス検出が可能であった。簡易 ELISA 法は，短時間内に多数の保毒虫検定を釉了することができるので RTYV の疫学的調査に有效な手法 であると考えられる。 